\title{
Relative Performance of Barley (Hordeum vulgare L.) Cultivars under Saline Water Condition
}

\author{
Nida Abdulrashid Patel* and M. Meena \\ School of Agriculture, Suresh Gyan Vihar University, Jagatpura, Jaipur, \\ Rajasthan-302017, India \\ *Corresponding author
}

\section{A B S T R A C T}

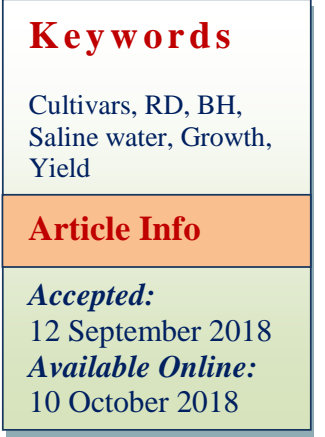

\section{Introduction}

Barley (Hordeum vulgare L) member of grasses family, it is a self-pollinated, diploid species with 14 chromosome number. It is a major cereal grain grown in temperate climates. It was one of the first cultivated grains, particularly in Eurasia as early as 10,000 year ago. Barley has been used as animal fodder, as a source of fermentable material for beer and certain distilled beverages, and as a compound of various health foods (Malcolmson et al., 2005).

Each $100 \mathrm{~g}$ of barley grain comprises $10.6 \mathrm{~g}$ protein, $2.1 \mathrm{~g}$ fat, $64.0 \mathrm{~g}$ carbohydrate, 50.0 $\mathrm{mg}$ calcium, $6.0 \mathrm{mg}$ iron, $31 \mathrm{mg}$ vitamin $\mathrm{B} 1$, $0.10 \mathrm{mg}$ vitamin $\mathrm{B} 2$ and $50 \mu \mathrm{g}$ folate (Vaughan et al., 2006). High protein barley is suited for animal feed. Malting barley is usually lower protein. Barley is the fourth largest cereal crop after maize, rice and wheat with 132 million tonnes produced annually. In India, barley was cultivated on $0.66 \mathrm{~m} \mathrm{ha}^{-1}$ area during 2015-16 with 1.62 million tonnes of production at an average productivity status of $24.7 \mathrm{q} \mathrm{ha}^{-1}$ (FAO, 2017) Rajasthan, it is have the first position with area 0.223 million $\mathrm{ha}^{-1}$ and production of 0.620 million tonnes with productivity of $2,774 \mathrm{~kg} \mathrm{ha}^{-1}$. This production is far below that of most of the states like Haryana (0.137million tonnes), 
Punjab (0.047 million ton) and Jammu and Kashmir (0.008 million ton). The production of barley can be increased either by increasing more area under cultivation or by increasing yield per unit area (Malcomson et al., 2005).

Barley is tolerant to saline water and sodic soil. Salinity is the concentration of dissolved salts in water or soil and is expressed in terms of concentration $\left(\mathrm{mg} \mathrm{L}^{-1}\right)$ or electrical conductivity ( $\mathrm{dS} \mathrm{\textrm {m } ^ { - 1 }}$ ). According to Grewal (2010) salinity is one of the major a biotic environmental stresses affecting agricultural productivity. Nearly $7 \%$ of world's total land area is affected by salinity. Salinity affects many morphological, physiological and biochemical processes, including seed germination, plant growth, water and nutrient uptake (Musyimi et al., 2007).Reduced yield and grain quality. However, plant species differ in their sensitivity or tolerance to salts (Basalah, 2010).

A clear understanding of plant response to salinity and the complex mechanisms of salt stress tolerance will be required for breeding of salt tolerant crop varieties. Germination and seedling growth under saline environment are the screening criteria which are widely used to select the salt tolerance genotype. Increasing the production of these crops under irrigation is an option. However, in a semi-arid country such as India good quality water for agricultural use is rapidly becoming a luxury. During the dryer time (winter months) of the year when these crops are grown water quality in irrigational areas is often not that good and high Electrical Conductivities (EC's) due to salinity may become a problem (Blumwald, 2002).

\section{Materials and Methods}

The field experiment was conducted at Agriculture Research farm, School of Agriculture, Suresh Gyan Vihar University,
Jagatpura, Jaipur, Rajasthan. Jaipur is situated in the eastern boundary of Thar Desert a semiarid land of Rajasthan at $26.9^{0}$ North latitude and $75.7^{\circ}$ East longitude at an altitude of 1417 meter from mean sea level. It has subtropical climate characterized by hot dry summer and cool dry winter. Jaipur lies in the "Semi-Arid Eastern Plains" agro climatic zone and the traditionally characterized as the wheat, pulse $\&$ oil seeds crop zone of Rajasthan.

The average maximum temperature during the month of May-June varies between $35.7^{0} \mathrm{C}$ and $42.1^{\circ} \mathrm{C}$, while the average minimum temperature varies between $8.2^{\circ} \mathrm{C}$ and $10.6^{\circ} \mathrm{C}$ during December-January, which is the coldest month of the year. The average annual rainfall of the region is about 500 to $700 \mathrm{~mm}$ which is mostly received between July to August and 80 to $100 \mathrm{~mm}$ in September. The average humidity of the tract is about 65 per cent. The climatic parameters of the study area can be understood from the Figure 1.

\section{Figure no. 1: Climatic parameters of Jaipur}

The soil at the location is sandy loam, Organic carbon \% (0.15), Available Nitrogen $\left(\mathrm{kg} \mathrm{ha}^{-1}\right)$ 250.6, Available $\mathrm{P}_{2} \mathrm{O}_{5}\left(\mathrm{~kg} \mathrm{ha}^{-1}\right) 25$, Available $\mathrm{K}_{2} \mathrm{O}\left(\mathrm{kg} \mathrm{ha}^{-1}\right) 162$, Electrical Conductivity (dS $\mathrm{m}^{-1}$ at $25^{0} \mathrm{C}$ ) 0.24 , Soil $\mathrm{pH} 8.2$.

The experiment was laid out in Randomized Block Design with 10 treatments three replicated thrice. The treatments consisted of 30 furrow irrigated raised bed (FIRB) methods. Number of spike meter ${ }^{-1}$ row length, length of spike $(\mathrm{cm})$, number of grain spike ${ }^{-1}$, test weight, grain yield $\left(\mathrm{q} \mathrm{ha}{ }^{-1}\right)$, straw yield ( $\mathrm{q}$ $\left.\mathrm{ha}^{-1}\right)$, harvest index (\%) were recorded at harvest. Economics of barley was also calculated viz. gross return, net return and B: $\mathrm{C}$ ration to find out the most profitable combination among the 10 combination under study. 


\section{Results and Discussion}

The data with respect to plant height have been summarized and tabulated in Table 1 the treatments significantly maximum plant height on $28.4,82.9$ and $100.37 \mathrm{~cm}$ observed under the cultivar RD 2552 at 30, 60 DAS and harvest. It remained at pat with RD 2052 at 30 DAS and at harvest. Plant height was significantly minimum on 19.6, 68.2 and $87.26 \mathrm{~cm}$ observed under cultivar RD 2097 and it was at par with the cultivars RD 2668 and RD 2097 at 30 DAS. The significant variation in plant height recorded in barley cultivars is due to genetic as well as environmental factors the interaction of both genetic and environmental factors results formation of phenotype with variable attributes including plant height. These results confirm the finding of Fishar et al., (2005), Bakht et al., (2007),

Days to 50 per cent heading was 4 and 5 days earlier in the cultivar RD 2592 and BH 946 as compared to other cultivars. At the same time days to 50 per cent heading was 19 days late in cultivar RD 2552, followed by other cultivars. It was observed that all the barley cultivars studied in present investigation registered significant variation for days to 50 per cent heading. Days from heading to maturity (grain filling) is an active stage for assimilates supply. It was not remarkably affected by salinity up to $4 \mathrm{dS} \mathrm{m}^{-1}$ treatment level but was influenced significantly at $8 \mathrm{dS}$ $\mathrm{m}^{-1}$. At $8 \mathrm{dS} \mathrm{m} \mathrm{m}^{-1}$ salinity level, a delay of 10.9 $\%$ (4.3 days) $92.4 \%$ (28 days) in accessions and $3.9 \%$ (1.5 days) $74.4 \%$ (21.2 days) in varieties was recorded as compared to the control. This is in agreement with earlier report in wheat (Grieve et al., 1992) and Mali (2016) also reported similar findings.

Days to 50 per cent maturity was 2 and 4 days earlier in the cultivar RD 2592 and BH 946 as compared to other cultivars. At the same time days to 50 per cent maturity was 18 days late in cultivar RD 2552, respectively. It was further observed that 50 per cent maturity significantly varies among the cultivars of barley used in present investigation. Days to Maturity was more strongly affected by salinity stress than both DTH and DHTM at 8 $\mathrm{dS} \mathrm{m}^{-1}$. This may be due to the extended exposure time to stress as well as the associated xylem input that result in the entrance of more salt ions into the plant, which would cause delay in maturity time according to (Yeo and Flower 1984). Such results are in conformity with Kinfemichael and Fisseha (2011).

The timing of heading and maturity are among the major traits that are related to the adaptation of cultivars under prevalent field conditions in particular areas. Quite often yield capacity is reduced in early maturity plants.

However, early heading along with late maturity results delayed leaf senescence which can extend grain filling duration and thus increases yield in cereal crops especially under stress environmental conditions according to Sanchezet al., (2002). Black gram and mung bean. The barely cultivar recorded significant variation in Table 2. Number of tillers plant ${ }^{-1}$ under the cultivar RD 2552 registered significantly maximum. It was at par with RD 2592 and BH 946. Significantly minimum number of tillers plant ${ }^{-1}$ was obtained in RD 2097 and it was as at par with RD 2715, respectively.

The number of tillers per plant is highly influenced by heredity and environment and is one of the important yield contributing traits that helps in identification or selection of high yielding tolerable genotypes under any stress condition including salinity. Number of tillers per plant has direct positive association with yield. Therefore, genotypes with more number 
of productive tillers even under stress will show increased productivity than the genotypes with less number of productive tillers. From the present investigation, it is clear that barley cultivars with more number of tillers per plant are also higher yielders. Same results have been also reported by Alam et al., (2005) and Mali (2016). Number of spike meter ${ }^{-1}$ row length as influenced by saline water. Barely cultivar RD 2552 was recorded significantly higher number of spike meter $^{-1}$ row length compared to other cultivars. The significantly minimum number of spike meter ${ }^{-1}$ row length observed under RD 2052 rest of the other cultivars. A varietal difference in respect number of spike meter ${ }^{-1}$ row length seems to be on account of higher LAI and efficient translocation of metabolites towards grain formation. These findings are confirmed with the results represent by Mishra et al., (2000) and Jat and Singh (2003).

The length of spike $\mathrm{m}^{-1}$ row length was different under the barley cultivar significantly higher spike length was observed under RD 2552 followed by RD 2592, BH 946 and RD 2035, respectively. Whereas, significantly minimum spike length was observed under cultivar RD 2052 Further, analysis revealed that the spike length of cultivar RD 2552 was $9.43 \mathrm{~cm}$ higher over other cultivars respectively. Studies were statistically significant with each other for the trait spike length. Spike length is one of the important yield contributing components. It is directly associated with yield. It has been found that a spike with more length bears more number of the grains. Therefore any change in spike length will have the direct impact on yield. It is observed from the present findings that some cultivars showed an adverse effect on spike length trait due to their sensitivity to salinity stress. However, RD 2552 and RD 2592 was less affected by salinity stress for their spike length as compared to other barley cultivars. These findings are in conformity with the results reported by Singh et al., (2017) and Mali (2016).

Table.1 Relative performance of barley cultivars under saline water condition on growth parameters

\begin{tabular}{|c|c|c|c|c|c|c|}
\hline \multirow[t]{2}{*}{ Cultivars } & \multirow{2}{*}{$\begin{array}{c}\text { Plant } \\
\text { Population } \\
\left(\mathbf{m}^{-2}\right) \text { At } \\
\text { Harvest }\end{array}$} & \multicolumn{3}{|c|}{ Plant height (cm) } & \multirow{2}{*}{$\begin{array}{c}\text { Days to } 50 \\
\text { per cent } \\
\text { heading }\end{array}$} & \multirow{2}{*}{$\begin{array}{l}\text { Days } 50 \text { per } \\
\text { cent maturity }\end{array}$} \\
\hline & & $\begin{array}{l}\text { At } 30 \\
\text { DAS }\end{array}$ & $\begin{array}{l}\text { At } 60 \\
\text { DAS }\end{array}$ & $\begin{array}{c}\text { At } \\
\text { Harvest }\end{array}$ & & \\
\hline RD2715 & 43.14 & 21.9 & 72.3 & 90.61 & 65.22 & 98.01 \\
\hline RD2035 & 45.06 & 24.2 & 77.8 & 94.62 & 76.31 & 108.32 \\
\hline RD2592 & 49.04 & 22.7 & 74.7 & 94.59 & 79.33 & 111.15 \\
\hline $\begin{array}{l}\text { RD2849 } \\
\end{array}$ & 45.01 & 23.1 & 75.6 & 93.57 & 70.21 & 102.23 \\
\hline RD2860 & 43.21 & 18.6 & 64.9 & 84.86 & 72.34 & 104.05 \\
\hline RD2552 & 52.91 & 28.4 & 82.9 & 100.37 & 82.33 & 113.25 \\
\hline RD2668 & 42.50 & 20.34 & 70.5 & 90.18 & 74.23 & 106.17 \\
\hline RD2097 & 38.95 & 19.6 & 68.2 & 87.26 & 63.21 & 95.03 \\
\hline BH946 & 48.14 & 26.5 & 79.4 & 96.48 & 78.66 & 109.11 \\
\hline RD2052 & 38.49 & 27.4 & 80.6 & 98.43 & 74.66 & 100.13 \\
\hline S.Em & 1.12 & 1.43 & 0.90 & 1.59 & 2.59 & 3.22 \\
\hline CD at $5 \%$ & 3.34 & 4.25 & 2.68 & 4.73 & 7.70 & 9.59 \\
\hline
\end{tabular}


Table.2 Relative performances of barley cultivars under saline water condition on plant Yield parameters and yield

\begin{tabular}{|c|c|c|c|c|c|c|c|c|}
\hline Cultivars & $\begin{array}{l}\text { Number } \\
\text { of tillers } \\
\text { plant }^{-1}\end{array}$ & $\begin{array}{c}\text { Number } \\
\text { of spike } \\
\text { meter }^{-1} \\
\text { row } \\
\text { length }\end{array}$ & $\begin{array}{c}\text { Spike } \\
\text { length } \\
(\mathrm{cm})\end{array}$ & $\begin{array}{l}\text { Number } \\
\text { of grain } \\
\text { spike }^{-1}\end{array}$ & $\begin{array}{c}\text { Test } \\
\text { weight } \\
(\mathrm{g})\end{array}$ & $\begin{array}{c}\text { Grain } \\
\text { yield (q } \\
\text { ha }^{-1} \text { ) }\end{array}$ & $\begin{array}{c}\text { Straw } \\
\text { yield (q } \\
\text { ha }^{-1} \text { ) }\end{array}$ & $\begin{array}{c}\text { Harvest } \\
\text { Index } \\
(\%)\end{array}$ \\
\hline RD2715 & 4.77 & 139.54 & 6.13 & 28.63 & 28.68 & 26.21 & 45.91 & 36.3 \\
\hline RD2035 & 6.76 & 145.53 & 8.16 & 33.39 & 36.87 & 39.41 & 52.61 & 42.8 \\
\hline RD2592 & 7.34 & 149.61 & 8.79 & 36.18 & 39.67 & 42.41 & 58.71 & 42.0 \\
\hline RD2849 & 5.55 & 145.91 & 6.62 & 31.18 & 34.59 & 36.66 & 41.81 & 46.7 \\
\hline RD2860 & 6.01 & 143.76 & 7.51 & 32.23 & 35.09 & 37.26 & 45.21 & 45.2 \\
\hline RD2552 & 7.51 & 150.91 & 9.43 & 37.68 & 40.21 & 45.21 & 67.71 & 40.0 \\
\hline RD2668 & 6.54 & 140.61 & 7.57 & 33.05 & 36.21 & 38.81 & 51.81 & 42.8 \\
\hline RD2097 & 4.33 & 138.00 & 5.50 & 24.66 & 26.78 & 18.26 & 31.51 & 36.7 \\
\hline BH946 & 7.18 & 148.10 & 8.46 & 35.43 & 38.85 & 41.73 & 64.21 & 39.4 \\
\hline RD2052 & 5.21 & 135.88 & 6.33 & 30.12 & 32.67 & 28.61 & 40.81 & 41.2 \\
\hline S.Em. \pm & 0.51 & 0.31 & 0.79 & 1.09 & 1.62 & 0.59 & 0.68 & 0.42 \\
\hline $\begin{array}{r}\text { C.D. at } \\
5 \%\end{array}$ & 1.52 & 0.93 & 2.36 & 3.24 & 4.82 & 1.79 & 2.02 & 1.25 \\
\hline
\end{tabular}

Table.3 Relative performances of barley cultivars under saline water condition on Economics of each treatment

\begin{tabular}{|c|c|c|c|c|c|c|}
\hline \multirow[t]{2}{*}{ Cultivars } & \multicolumn{2}{|c|}{ Yield price ( $\left(\mathcal{Y} \mathrm{ha}^{-1}\right)$} & \multirow{2}{*}{$\begin{array}{l}\text { Gross } \\
\text { realization } \\
\left(₹ \mathrm{ha}^{-1}\right)\end{array}$} & \multirow{2}{*}{$\begin{array}{l}\text { Total } \\
\text { Cost } \\
\left(\text { ₹ ha }^{-1}\right)\end{array}$} & \multirow{2}{*}{$\begin{array}{l}\text { Net } \\
\text { realization } \\
(₹ \text { ha }\end{array}$} & \multirow{2}{*}{$\begin{array}{ll}\text { B: } & \text { C } \\
\text { Ratio } & \end{array}$} \\
\hline & Grain & Straw & & & & \\
\hline RD 2715 & 26.2 & 45.91 & 46523.0 & 35565 & 10958.0 & $1: 1.3$ \\
\hline RD 2035 & 39.4 & 52.61 & 65330 & 35565 & 29468.0 & $1: 1.8$ \\
\hline RD 2592 & 42.4 & 58.71 & 70613.0 & 35565 & 34598.0 & $1: 2.0$ \\
\hline RD 2849 & 36.66 & 41.81 & 58368.0 & 35565 & 22803.0 & $1: 1.6$ \\
\hline RD2860 & 37.26 & 45.21 & 60138.0 & 35565 & 24573.0 & $1: 1.7$ \\
\hline RD 2552 & 45.2 & 67.71 & 768130.0 & 35565 & 41248.0 & $1: 2.2$ \\
\hline RD 2668 & 38.81 & 51.81 & 64055.0 & 35565 & 2849.0 & $1: 1.8$ \\
\hline RD 2097 & 18.26 & 31.51 & 32275.0 & 35565 & 3290.0 & $1: 1.0$ \\
\hline BH 946 & 41.73 & 64.21 & 71425.6 & 35565 & 35860.0 & $1: 2.0$ \\
\hline RD 2052 & 28.6 & 40.81 & 47993.0 & 35565 & 12428.0 & $1: 1.3$ \\
\hline
\end{tabular}


Fig.1 Mean weekly meteorological data during crop growth period (rabi, 2016-2017)

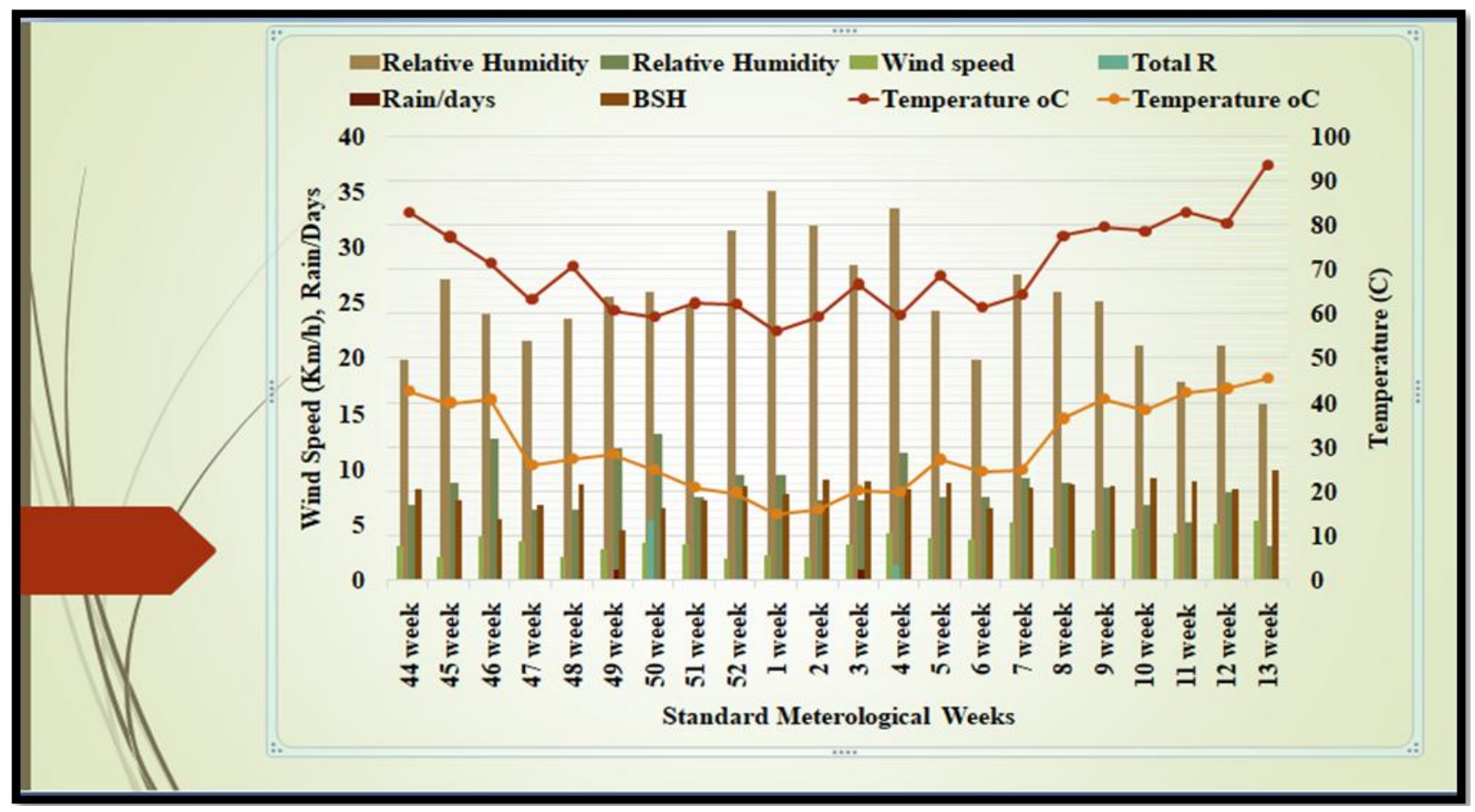

Fig.1 Bird eye view of experimental plot

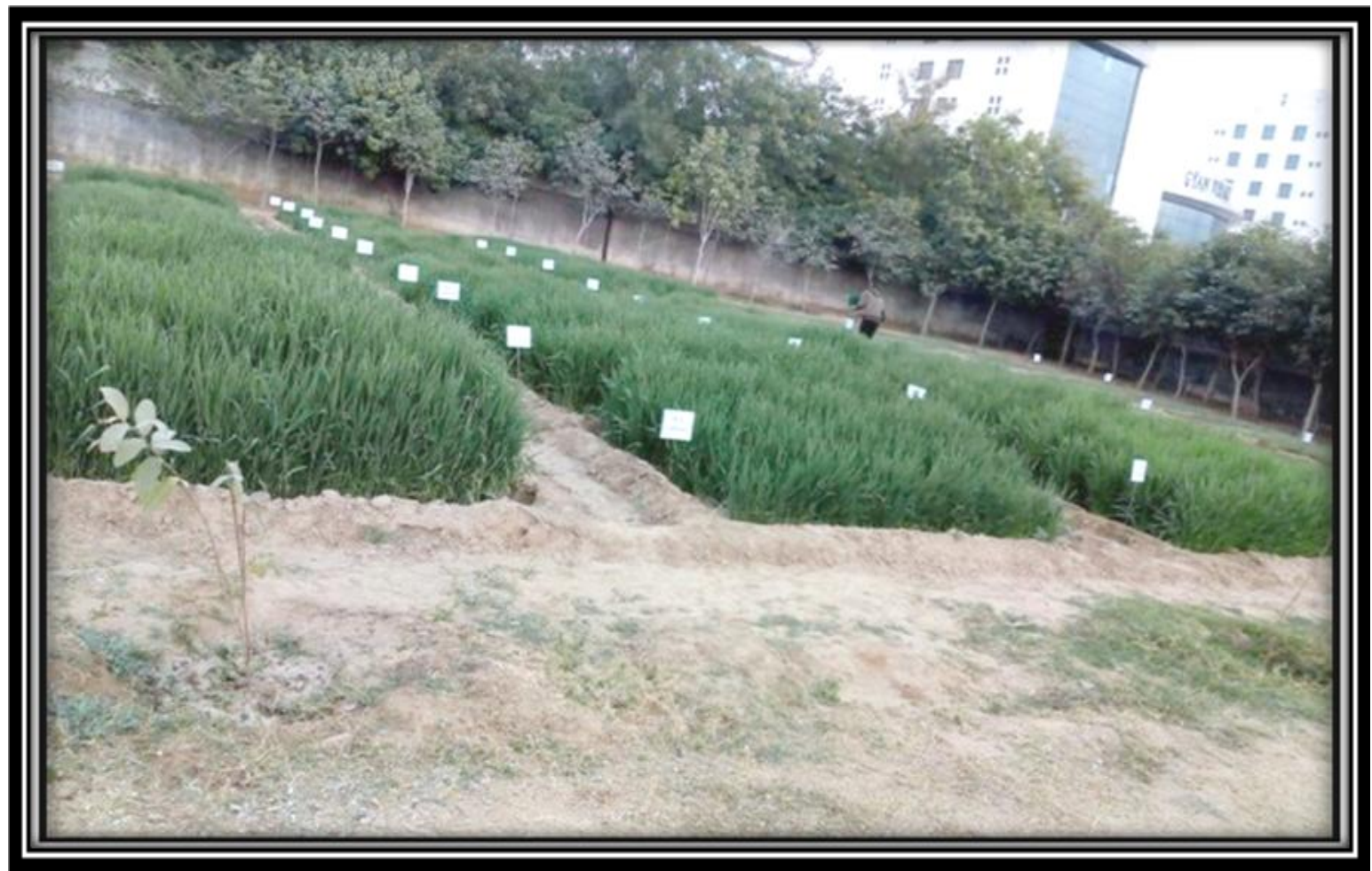


Number of grain spike $^{-1}$ was significant. Among all the cultivars RD 2552 recorded significantly higher number of grains spike ${ }^{-1}$ compared to other cultivars. The significantly minimum number of grains spike $^{-1}$ was obtained in RD 2097 over other cultivars. All the cultivars were found statistically significant with each other thus exerted variable effect on number of grains spike ${ }^{1}$ Our results are in conformity with Stapper and Fischer (1990), Singh et al., (1996),

Test weight are presented statistical analysis of data collected showed that saline water exerted significant effect on test weight. Among the all cultivar RD 2552 recorded marginally higher test weight significantly minimum test weight was obtained in RD 2097 it was at par with RD 2715, respectively. Also, the suitable genetic behavior of these three cultivars even under stress environment may leads to an increase in photosynthetic process and accumulation of carbohydrates in grains to produce heavy grains. Similar results were also reported by Alam et al., (2007) and Zaidan (2007),

Grain yield as influenced by saline water have been presented. Revealed that the grain yield was significantly influenced by different cultivars Cultivar RD 2552 was recorded significantly higher grain yield followed by RD 2592 and BH 946 whereas significantly minimum grain yield was observed under cultivar RD 2097 compared to other cultivars. Yield is not an independent character but a product of a number of constellation of yield contributing characters such as tillers per plant, spike length, grain per spike, test weight which form the 'sink' and the harvest index which are considered directly related to yield. In the present study, the higher yield of barley cultivar RD 2552 under salinity may be attributed to its higher number of tillers, long spike length, more number of grains per spike, higher test weight and harvest index.
Same is the case with other cultivars RD 2592 and $\mathrm{BH}$ 946. These findings are in conformity with the results reported by Sardhana et al., (2002) Jat and Singh (2003).

The straw yield was significantly influenced by different cultivars. Among the all cultivars maximum straw yield (67.71 $\left.\mathrm{q} \mathrm{ha}^{-1}\right)$ was recorded in cultivar RD 2552, being significantly higher than all other cultivars. However, significantly lowest straw yield was obtained in RD 2097 (31.51 q ha $\left.{ }^{-1}\right)$, respectively. All the barley cultivars under study showed significant variation and thus exerted variable effect on straw yield. This was mainly due to the fact that grain and biological yields increased almost in different pattern during the period of season. Similar results were founded by Chandra and Das (2000) and Cui et al., (2000).

The harvest index was significantly influenced by different cultivars. Among the all cultivar, significantly maximum harvest index was recorded in RD 2849 followed by RD 2552 and RD 2592, respectively. However, significantly minimum harvest index was recorded in RD 2715 being, statistically at par with RD 2668. A significant and positive correlation between straw yield and dry matter accumulation at harvest showed dependence of straw yield on DMA at harvest. The biological yield is a function of grain and straw yield. Thus significant increase in biological yield of cultivar could be ascribed to increase in grain and straw yield. These results are in close agreement with finding of Rawat (2011) and Singh et al., (2013).

\section{Economics}

The economics on different cultivars are given in Table 3. It was showed that cultivar RD 2552 gave the highest net return and benefit cost ratio which was found 
statistically superior over RD 2592. This might be due to high yielding ability of the cultivar RD 2552 as compared to RD 2592 but similar cost of cultivation, which results in high net return and benefit cost ratio. Singh et al., (2013) also reported higher net return and benefit cost ratio in cultivar RD 2552 . These results are in close conformity with the results of Ram et al., (2010).

Among the 10 promising barley cultivars, RD-2552, RD-2592 and BH-946 were quite encouraging under salinity condition in respect to growth, yield and yield contributing characters. As yield is a constellation of yield contributing characters which includes number of tillers per plant, spike length, number of grains per spike, 1000 grain weight. Since RD-2552, RD-2592 and BH946 cultivars exhibited highest number of tillers per plant, spike length, number of grains per spike, 1000 grain weight, therefore, they were also the high yielders among the rest of promising barley cultivars tested under salinity condition. Thus, it is suggested that these cultivars should be grown and promoted to salinity affected regions of Rajasthan.

\section{References}

Alam, M.Z., Haider, S.A. and Paul, N.K. (2007). Yield and yield components of barley (Hordeum vulgare L.) cultivars in relation to nitrogen fertilizer. Journal of Applied Science and Research, 3(10): 1022-1026.

Alam, M.Z., Haider, S.A. and Paul, N.K., (2005). Effects of sowing time and nitrogen fertilizer on barley (Hordeum vulgare L.). Bangladesh Journal of Botany, 34(1): 27-30.

Bakht, J., Qamer, Z., Shafi, M., Akber, H., Rahman, M., Ahmad, N., and Khan, M., Javed, (2007). Response of different wheat varieties to various row spacing.
Sarhad Journal of Agriculture, 23 (4): 839-846.

Basalah, M.O., (2010). Action of salinity on seed germination and seedling growth of (Solanumm melongena L.). Journal of Agricultural Research Kafer El-Sheikh Universitsy, 36(4):64-73.

Blumwald, E., (2002). Engineering salt tolerance in plant. Current opinion in biotechnology, 13(2):146-150.

Chandra, K. and Das, A. K., (2000). Correlation and inter correlation of Physiological parameters in rice under rainfed transplanted condition. Indian Journal of Agronomy, 19 (2): 251-254.

Cui, J., Kusutani, A., Toyata, M., and Asanuma, K., (2000). Studies on the varietal differences of harvest index and morphological characteristics of rice. Japanese Journal of Crop Science, 69 (3): 359-364.

FAO, (2017). http://www.fao.org/faostat/ en/\#data/QC

Fisher, R.A., Sayre, K. and Monasterio, I., (2005). The effect of raised bed planting and irrigated wheat yield influenced by variety and row spacing. International Journal of Scientific Reports, 1 (3):121141.

Grewal, H.S., (2010). Water uptake, water use efficiency, plant growth and ionic balance of wheat, barley, canola and chickpea plants on a sodic vertical with variable subsoil $\mathrm{NaCl}$ salinity. Agriculture Water Mangement, 97(3):148-156.

Grieve, M.M., Giuzio, L., Caro, A. and Flagella, Z., (1992). Relationships between nitrogen utilization and grain technological quality in durum wheat Nitrogen translocation and nitrogen use efficiency for protein. Indian Journal of Agronomy, 103 (6):1487-1494.

Jat, L.N. and Singh, S.M., (2003). Growth, yield attributes and yields of wheat (Triticum aestivum) under different 
planting pattern or cropping systems and varieties. Indian Journal of Agronomy, 49: 41-43.

Kinfemichael, S.G. and Fisseha, I.M., (2011). Effects of salinity on days to heading (DTH), days from heading to maturity (DHTM) and days to maturity (DTM) of tef [Eragrostis tef (Zucc.) Trotter] accessions and varieties in Ethiopia. Asian Journal of Agricultural Sciences, 3 (4): 250-256.

Malcolmson, N., Nowkirkm, R. and Carson, G., (2005). Expanding opportunities for barley food and geed through product innovation. Feed and food quality; $18^{\text {th }}$ National American Barley Research Workshop $4^{\text {th }}$ Canadian Barley Symposium pp.2-4

Mali. H., (2016). Performance of barley (Hordium vulgare L.) varieties under varying precision nutrient management practices. Ph.D (Agri) thesis, MPUAT, Udaipur.

Mishra, D.K., Khan, R.A. and Vaghel, M.S., (2000). Stability of wheat varieties under various dates of sowing. Annals of Agricultural Research, 21 (4): $564-$ 566.

Musyimi, D.M., Netondo, G.W. and Ouma, G., (2007). Effects of salinity on growth and Photosynthesis of avocado seedling. International Journal of Botany, 4(3):78-84.

Ram, H., Singh, B. and Sharma, A., (2010). Effect of time of sowing on the field performance of barley (Hordeum vulgare L.) in Punjab. Journal of Research Punjab Agricultural University, 47 (3 \& 4): 132-35.

Rawat, D.S., (2011). Performance of dual purpose barley (Hordeum vulgare L.) varieties under varying seed rates and fertility management M.Sc (Agri) Thesis, Department of Agronomy, MPUAT, Udaipur
Sanchez, P.K., Subudhi, D.T., Rosenow, and Nguyen, H.T., (2002). Mapping QTLs associated with drought resistance in sorghum (Sorghum bicolor L.). Journal of Plant Molecular Biology, 48(5): 713726.

Sardana, V., Sharma, S.K. and Randhawa, A.S., (2002). Performance of wheat (Triticum aestivum L.) varieties under different sowing dates and nitrogen levels in the sub-montane region of Punjab. Indian Journal of Agronomy, 47 (3): 372-377.

Singh, A., Singh, R.D. and Awasthi, R.P. (1996). Organic and inorganic sources of fertilizer for sustained productivity in rice (Oryza sativa) - wheat (Triticum aestivum $L$.) sequence on humid hilly soils of Sikkim. Indian Journal of Agronomy 41(2):191-194.

Singh, A.K., George, and P.J. Prasad, P., (2017). Effect of Seed Bed and Different Sources of Nitrogen on Growth and Yield of Barley (Hordeum vulgare L.). International Journal of Current Microbiology and Applied Sciences, 6(8): 748-752.

Singh, D., Singh, D.R., Nepalia, V. and Kumari, A., (2013). Agro-economic performance of dual purpose barley (Hordeum vulgare L.) varieties under varying seed rate and fertility levels. Annals of Agriculture Research, 34 (3): 325-229.

Stapper, M. and Fischer, R.A. (1990). Genotypes, sowing date and plant spacing influence on high yielding irrigated wheat in Southern New Wales. Australia. Journal. Agriculture Research, 41(2): 997-1019.

Vaughan, J.G., Judd, P.A. and Bellamy, D. (2006). The oxford book of health foods. A comprehensive guide to natural remedies Publisher Oxford University- press great clarendon street, 
Oxford. http://books.google.co.in/books pp-37.

Yeo, R.B. and Flower N.P., (1984). Response of dwarf durum and aestivum wheat varieties to nitrogen. Indian Journal of Agronomy, 29 (3): 341-350.
Zeidan, M.S., (2007). Response of some barley cultivars to nitrogen sources and rates grown in alkaline sandy soil. Journal of Agriculture and Biological Science, 3(6): 934-938.

\section{How to cite this article:}

Nida Abdulrashid Patel and Meena, M. 2018. Relative Performance of Barley (Hordeum vulgare L.) Cultivars under Saline Water Condition. Int.J.Curr.Microbiol.App.Sci. 7(10): 17241733. doi: https://doi.org/10.20546/ijcmas.2018.710.198 